\title{
Palm Oil Microencapsulation by Coacervation, Thin Layer Drying, and Silica Dioxide Absorption Technique
}

\author{
Nur Wulandari ${ }^{1,2}$, Tien R. Muchtadi', Rachel Irene ${ }^{1}$ \\ ${ }^{1}$ Department of Food Science and Technology, Faculty of Agricultural and Engineering Technology, Bogor \\ Agricultural University, Bogor, Indonesia \\ ${ }^{2}$ Southeast Asian Food and Agricultural Science and Technology Center, Bogor Agricultural University, \\ Indonesia \\ Email: wulandari n@ipb.ac.id
}

Received 15 July 2015; accepted 21 August 2015; published 25 August 2015

\begin{abstract}
Indonesia is the largest palm oil producer in the world. The content of $\beta$-carotene in palm oil, which can act as pro-vitamin A, is relatively high, so it has great potential for overcoming cases of vitamin A deficiency. By microencapsulation process of palm oil, $\beta$-carotene content in palm oil will be more stable and have a longer shelf life. There are three methods of microencapsulation used in this study, namely coacervation, thin-layer drying, and $\mathrm{SiO}_{2}$ absorption technique, which theoretically are suitable for encapsulating $\beta$-carotene in palm oil. The aim of this research is to compare and find the most suitable method of microencapsulation process of palm oil to obtain the highest $\beta$-carotene content and retention. Results show that those three methods are significantly different in affecting water absorption, solubility in water, yield, microencapsulation efficiency, $\beta$-carotene content, and retention of microencapsulated palm oil. The microencapsulated palm oil made from thin layer drying method has the highest $\beta$-carotene content at $200.16 \mu \mathrm{g} / \mathrm{g}$ and $\beta$-carotene retention of $\mathbf{6 8 . 8 9 \%}$. It also has low water absorption and high water solubility, so it can be applied as a powder premix in food as vitamin $A$ supplement.
\end{abstract}

\section{Keywords}

$\beta$-Carotene, Microencapsulation, Palm Oil, Thin Layer Drying, Vitamin A

\section{Introduction}

Indonesia is the largest palm oil producer in the world. Based on [1], Indonesia has reached 5.16 million hectares of palm oil plantations with crude palm oil production has reached 14,038,148 tons in 2010. Palm oil is a better source of pro-vitamin A than other natural ingredients. According to [2], the uniqueness of palm oil compared to other oil is its high content of $\beta$-carotene, equivalent to 60,000 IU of vitamin A activity. However, $\beta$-carotene is extremely unstable, especially when exposed to oxygen, high temperature, and metals. 
In order to increase palm oil $\beta$-carotene utilization, it is important to protect and maintain its stability, for example, by microencapsulation process. Research on palm oil microencapsulation have been conducted by coacervation [3], spray drying, thin-layer drying, orifice process, and $\mathrm{SiO}_{2}$ absorption techniques. However, it is not known yet which method is the best for producing microencapsulated palm oil (MPO) in the perspective of $\beta$-carotene content and retention. The aim of this research is to compare and find methods of microencapsulation process of palm oil to obtain the highest $\beta$-carotene content and retention.

\section{Material and Method}

\subsection{Material and Equipment}

The raw material used in this study were the liquid fraction of crude palm oil (CPO) obtained from a palm oil industry in Indonesia, and some coating materials such as arabic gum, gelatin, maltodextrin, carboxyl methyl cellulose (CMC), and $\mathrm{SiO}_{2}$. Other materials used were phosphoric acid and chemicals for analyzing palm oil and MPO. Equipment used in this study were hotplate and magnetic stirrer (Mega-mix PMC), homogenizer (IKA Labortechnik basic RW16), centrifuge (Hermle Z 383 K), freeze dryer (Christ Alpha 2 - 4 Ldplus), high performance liquid chromatography (HPLC, Shimadzu, Japan), analytical balance, vacuum oven, polarized light microscope (Olympus C-35AD-4), and glassware.

\subsection{Method}

\subsubsection{Preparation of Palm Oil}

Liquid fraction of $\mathrm{CPO}$ was degummed to separate impurities. One liter of $\mathrm{CPO}$ was heated over $80^{\circ} \mathrm{C}$, and then $0.15 \mathrm{~mL}$ of $85 \%$ phosphoric acid was added. The mixture was stirred for 15 minutes and allowed to stand for 15 minutes. The oil then was filtered. Degummed palm oil then was analyzed for its water content [4], ash content [5], protein content [4], free fatty acid content [6], peroxide value [7], and $\beta$-carotene content [8].

\subsubsection{Production of Microencapsulated Palm Oil}

Coacervation technique used mixed of arabic gum and gelatin as coating materials in the ratio of 1:1. Degummed palm oil was added with the comparison of 1:2 to the coating material to form an emulsion. After that, the $\mathrm{pH}$ of the emulsion was lowered to 4 by $0.1 \mathrm{~N} \mathrm{HCl}$. $0.37 \%$ formalin was added as much as $0.15 \%(\mathrm{v} / \mathrm{v})$ as crosslinking agent [9], and then it was stirred at $300 \mathrm{rpm}$ for 20 minutes. The emulsion was cooled to $5^{\circ} \mathrm{C}$, and $0.1 \mathrm{~N}$ of $\mathrm{NaOH}$ was added to increase the $\mathrm{pH}$ to 9.0. The emulsion was separated to obtain solid and liquid phase by centrifugation. The solid part was washed 2 times, followed by freeze-drying at $50^{\circ} \mathrm{C}$ for 72 hours to form MPO.

Thin layer drying technique used gelatin (3\%), CMC (1\%), and maltodextrin (7.5\%), that were mixed and added with $78 \%$ water and heated to $60^{\circ} \mathrm{C}$. The temperature of the mixture was reduced to $45^{\circ} \mathrm{C}$ then homogenized for 8 minutes at $1425 \mathrm{rpm}$. The mixture then was added with $11 \%$ of degummed palm oil, and homogenized for 27 minutes. The mixture was layered in a drying tray coated by plastic sheet, continued by vacuum drying at $60^{\circ} \mathrm{C}$ for 5 hours. Dried layer of emulsion was being powdered to obtain MPO.

$\mathrm{SiO}_{2}$ absorption technique were using degummed palm oil that was mixed with micro porous $\mathrm{SiO}_{2}$ in the ratio of 1:1, and was stirred until well mixed in 5 - 10 minutes to form MPO.

\subsubsection{Analysis of Microencapsulated Palm Oil}

MPO that were made were characterized for their chemical properties, carotene content and carotene retention. Some other analysis conducted were calculation of the yield [10], analysis of microencapsulation efficiency [11], and analysis of encapsulated oil in MPO [12]. MPO were also being analyzed for its physical properties such as water absorption [13], and solubility. Data of MPO characteristics then were analyzed statistically using OneWay ANOVA test, to observe any significant differences from those three types of MPO.

\section{Results and Discussions}

\subsection{Preparation of Palm Oil}

Palm oil was processed with a minimum refinery step through degumming process to minimize loss of $\beta$-caro- 
tene content. Degumming is a separation process between oil from sap or slime which consists of phospholipids, proteins, residues, carbohydrates, water, and resin [14]. In this research, dry degumming process was used by adding $85 \%$ phosphoric acid solution at $80^{\circ} \mathrm{C}$. Results in Table 1 showed that the degummed palm oil did not contain ash and protein. Impurities contained in crude palm oil could be effectively separated through degumming process. This result was supported by the peroxide value which also decreased after degumming process. Metals are catalyst in the oil oxidation process to form peroxide [2]. Phosphoric acid added during degumming process can initiate the formation of clots that facilitate the deposition of dirt, lowered peroxide, and improve color stability of oil [14]. Free fatty acid content and water content that were increase during degumming process possibly due to hydrolysis reaction, were still meet the quality requirements from National Standards of Indonesia (SNI 01-0016-1998). Degumming process also decreased $\beta$-carotene content of palm oil from 366.18 to $290.55 \mu \mathrm{g} / \mathrm{g}$. Degradation of $\beta$-carotene are generally caused by light, oxygen, metals, and high temperature. Degumming process was carried out at $80^{\circ} \mathrm{C}$ that could cause damage of $\beta$-carotene.

\subsection{Production of Microencapsulated Palm Oil}

MPO were made by using three methods, namely coacervation, thin-layer drying, and absorption of $\mathrm{SiO}_{2}$ techniques. The appearance of MPO can be seen in Figure 1. The MPO's were shaped as granules or powder with yellowish color.

Coacervation technique has advantages due to the easiness of obtaining the materials used and for its low temperature used, although the procedure was time consuming. The exposure of $\beta$-carotene in palm oil to the environment was more intensive, so that the retention of $\beta$-carotene can be low. Another drawback for this technique was the use of formaldehyde as a cross-linking agent. Formaldehyde is banned from used in food because it's carcinogenicity.

Thin layer drying technique has some advantages such as the coating materials and equipment can be easily obtained. However, the drying process that was carried out at temperature of $60^{\circ} \mathrm{C}$ for 5 hours potentially could damage $\beta$-carotene content. Another drawback was the capacity of vacuum drier that was limited so it can't be used to produce large quantity of MPO.

$\mathrm{SiO}_{2}$ absorption technique was very easy to apply and does not require long time and specific equipment. $\beta$ carotene was more protected from the damaged because this method did not involve $\mathrm{pH}$ adjustment and high temperature process. However, $\mathrm{SiO}_{2}$ is not a compound commonly used so that it is difficult to be obtained.

\subsection{Characteristics of Microencapsulated Palm Oil}

Chemical characteristics of MPO are presented in Table 2. Three types of MPO had water content less than 3\%, which was also affected by the coating material used. MPO is expected to have a low moisture content to avoid the hydrolysis reaction that can make the oil and $\beta$-carotene damaged.

Total oil content was affected by the amount of palm oil added, that was determined by encapsulated oil content. $\beta$-carotene content in MPO was lower than that of degummed palm oil. MPO made by thin-layer drying has the highest content $\beta$-carotene as much as $200.16 \mu \mathrm{g} / \mathrm{g}$ with the retention of $68.89 \%$. $\beta$-carotene is easily degraded by the process of oxidation, heat, and light. MPO made by coacervation technique contain of 42.83

Table 1. Analysis of palm oil before and after degumming.

\begin{tabular}{|c|c|c|}
\hline \multirow[t]{2}{*}{ Parameter } & \multicolumn{2}{|c|}{ Palm Oil } \\
\hline & Before Degumming Process & After Degumming Process \\
\hline Water content (g/100g) (wet basis) & $0.13^{\mathrm{a}}$ & $0.16^{\mathrm{a}}$ \\
\hline Ash content (g/100g) (wet basis) & $0.02^{\mathrm{a}}$ & $0.00^{\mathrm{a}}$ \\
\hline Protein content (g/100g) (wet basis) & $0.22^{\mathrm{a}}$ & $0.00^{\mathrm{b}}$ \\
\hline Free fatty acid level (\%) & $3.00^{\mathrm{a}}$ & $4.60^{\mathrm{b}}$ \\
\hline Peroxide value (mg/g equivalent $\mathrm{O}_{2}$ ) & $65.61^{\mathrm{a}}$ & $18.21^{\mathrm{b}}$ \\
\hline$\beta$-carotene content $(\mu \mathrm{g} / \mathrm{g})$ & $366.18^{\mathrm{a}}$ & $290.55^{\mathrm{b}}$ \\
\hline
\end{tabular}

The same letters after the numbers in the same row indicates no significant difference $(\mathrm{p}>0.05)$. 
Table 2. Properties of microencapsulated palm oil.

\begin{tabular}{|c|c|c|c|}
\hline \multirow[t]{2}{*}{ Parameter } & \multirow[b]{2}{*}{ Coacervation } & \multicolumn{2}{|c|}{ Method of Microencapsulation } \\
\hline & & Thin Layer Drying & $\mathrm{SiO}_{2}$ Absorption \\
\hline Water content (g/100g) (wet basis) & 0.28 & 2.58 & 0.11 \\
\hline Total fat content (g/100g) (wet basis) & 95.66 & 37.89 & 47.38 \\
\hline$\beta$-carotene content $(\mu \mathrm{g} / \mathrm{g})$ & $42.83^{\mathrm{a}}$ & $200.16^{\mathrm{b}}$ & $1.75^{\mathrm{c}}$ \\
\hline$\beta$-carotene content retention (\%) & $14.74^{\mathrm{a}}$ & $68.89^{\mathrm{b}}$ & $0.6^{\mathrm{c}}$ \\
\hline Yield (\%) & $15.35^{\mathrm{a}}$ & $21.78^{\mathrm{b}}$ & $100^{\mathrm{c}}$ \\
\hline Microencapsulation efficiency (\%) & $7.37^{\mathrm{a}}$ & $37.93^{\mathrm{b}}$ & $47.41^{\mathrm{c}}$ \\
\hline Encapsulated palm oil (\%) & 32.03 & 50.97 & 49.77 \\
\hline Water absorption (\%) & $149.51^{\mathrm{a}}$ & $89.88^{\mathrm{b}}$ & $74.53^{\mathrm{c}}$ \\
\hline Solubility (\%) & $67.41^{\mathrm{a}}$ & $127.41^{\mathrm{b}}$ & $46.42^{\mathrm{c}}$ \\
\hline
\end{tabular}

The same letters after the numbers in the same row indicates no significant difference $(p>0.05)$.

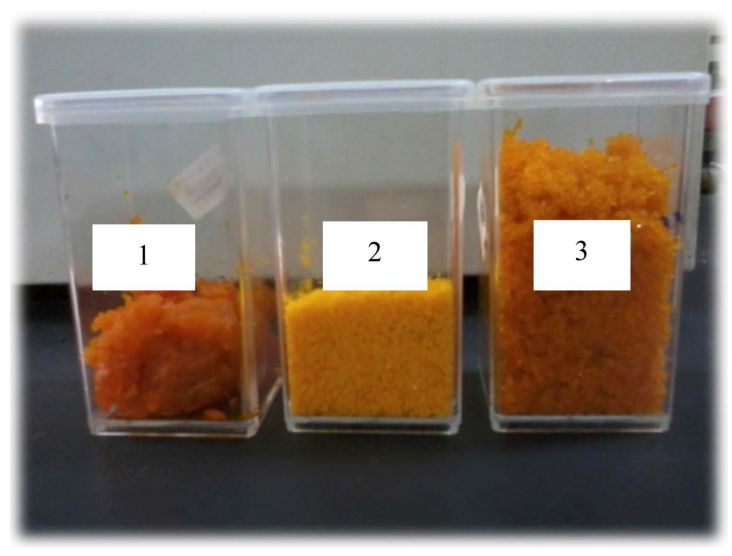

Figure 1. The appearance of microencapsulated palm oil (MPO): MPO by coacervation technique (1), MPO by thin-layer drying (2), MPO by $\mathrm{SiO}_{2}$ absorption (3).

$\mu \mathrm{g} / \mathrm{g} \beta$-carotene with $14.74 \%$ retention. The loss of $\beta$-carotene in this method may occur during $\mathrm{pH}$ adjustment and during drying process of MPO that still can be exposed to light. Meanwhile, the content of $\beta$-carotene in MPO made by $\mathrm{SiO}_{2}$ absorption was very low, contain $1.75 \mu \mathrm{g} / \mathrm{g}$ that equal to $0.60 \%$ retention. This was caused by the property of $\mathrm{SiO}_{2}$ that was very stable to chemical reactions that could not release $\beta$-carotene during analysis.

The highest yield was obtained from $\mathrm{SiO}_{2}$ absorption technique, because it was made only by mixing $\mathrm{SiO}_{2}$ and palm oil without any centrifugation and drying process. The highest microencapsulation efficiency also was obtained by $\mathrm{SiO}_{2}$ absorption technique, while the coacervation technique only had 7.37\%. The percentage of encapsulated oil during microencapsulation process was approximately about $50 \%$ for thin layer drying and $\mathrm{SiO}_{2}$ absorption technique except for coacervation technique with only 32.03\%. Several factors that affect the efficiency of microencapsulation are the concentration of the polymer coating, the ratio of DP/CP, and the speed of removal of the solvent [15]. In coacervation technique, the concentration of coating material used is very small, whereas in the $\mathrm{SiO}_{2}$ absorption method, the concentration of coating material used is proportional to the concentration of oil added. MPO produced by thin-layer drying has a better efficiency than the product of coacervation technique because its ratio of DP/CP and its drying speed was higher.

Physical properties of MPO that was studied were the water absorption and solubility in water (Table 2). MPO produced by coacervation technique had the highest water absorption. This was caused by the porous structure of MPO after freeze drying process that easily absorbing water. MPO produced by thin layer drying has the highest solubility. This occurs because the coating materials used are CMC, gelatin, and maltodextrin 
that have good solubility in water.

\section{Conclusion}

According to the chemical and physical properties, microencapsulation of palm oil was best resulted by thin layer drying technique. This method produced microencapsulated palm oil with the average $\beta$-carotene content of $200.16 \mu \mathrm{g} / \mathrm{g}$ and $\beta$-carotene retention of $68.89 \%$. Microencapsulated palm oil by thin layer drying also had suitable physical properties, with solubility in water of $127.41 \%$ and water absorption of $89.88 \%$, which was appropriate to be used as powder premix.

\section{References}

[1] Badan Pusat Statistik (2012) Luas Tanaman Perkebunan Besar Menurut Jenis Tanaman, Indonesia (000 Ha), 1995-2012 [(terhubung berkala). http://www.bps.go.id/tab_sub/view.php?kat=3\&tabel=1\&daftar=1\&id_subyek=54\&notab=1

[2] Sumarna, D. (2006) Degumming Process of CPO (Crude Palm Oil) Using Ultrafiltration Membrane (Proses Degumming CPO (Crude Palm Oil) Menggunakan Membran Ultrafiltrasi). Jurnal Teknologi Pertanian, 2, 24-30.

[3] Siow, L.F. and Ong, C.S. (2013) Effect of pH on Garlic Oil Encapsulation by Complex Coacervation. Journal of Food Process Technology, 4, 1-5.

[4] Association of Official Analytical Chemist (1995) Official Method of Analysis of the Association of Official Agricultural Chemist. AOAC International, Washington DC.

[5] National Standardization Agency (1992) Methods for Analysing Food and Beverages (Cara Uji Makanan dan Minuman). SNI 01-2891-1992. Badan Standardisasi Nasional, Jakarta.

[6] National Standardization Agency (1998) Crude Palm Olein. SNI 01-0016-1998. Badan Standardisasi Nasional, Jakarta.

[7] Association of Official Analytical Chemist (1990) Official Method of Analysis of the Association of Official Agricultural Chemist. AOAC International, Washington DC.

[8] DeVries, J.W. and Silvera, K.R. (2002) Determination of Vitamin A (Retinol) and E (Alpha Tocopherol) in Foods by Liquid Chromatography: Collaborative Study. Journal of AOAC International, 85, 424-434.

[9] Zuidam, N.J. and Nedovic, V. (2010) Encapsulation Technologies for Active Food Ingredients and Food Processing. Springer, New York. http://dx.doi.org/10.1007/978-1-4419-1008-0

[10] Ahn, J.H., Kim, Y.P., Seo, E.M., Choi, Y.K. and Kim, H.S. (2007) Antioxidant Effect of Natural Plant Extracts on the Microencapsulated High Oleic Sunflower Oil. Journal of Food Engineering, 84, 327-334. http://dx.doi.org/10.1016/j.jfoodeng.2007.05.029

[11] Komari. (1997) Encapsulation Efficiency and Model of Microencapsulated Vitamin C Release Using Polymer Deposition Technique. (Efisiensi Enkapsulasi dan Model Rilis Vitamin C yang Dienkapsulasi dengan Teknik Polymer Deposition). Prosiding Seminar Teknologi Pangan 1997.

[12] Shahidi, F. and Wanasundara, P.K.J.P.D. (1997) Extraction and Analysis of lipids. In: Akoh, C.C. and dan Min, D.B., Eds., Food Lipids, Chemistry Nutrition and Biotechnology, 2nd Edition, Marcel Dekker Inc. New York.

[13] Messinger, J.K., Rupnow, J.H., Zeece, M.G. and Anderson, R.L. (1987) Effect of Partial Proteolysis and Succinylation on Functionality of Corn Germ Protein Isolate. Journal of Food Science, 52, 1620-1624. http://dx.doi.org/10.1111/j.1365-2621.1987.tb05891.x

[14] Lin, L., Rhee, K.C. and Koseoglu, S.S. (1998) Recent Progress in Membrane Degumming of Crude Vegetable Oil on a Pilot-Plant Scale. Food Protein R\&D Center, Texas A\&M University, College Station.

[15] Yeo, Y. and Park, K. (2004) Control of Encapsulation Efficiency and Initial Burst in Polymeric Microparticle Systems. Archives of Pharmacal Research, 27, 1-12. http://dx.doi.org/10.1007/BF02980037 